candidates offer one or other of the languages, and the results are generally satisfactory.

The Commercial Class. This course aims at preparing students for the Separate Subjects Certificates issued by the London Chamber of Commerce; it is not intended to be strictly vocational, but to assist in giving those students who contemplate a business career a good general education. Practical experience is gained by the students in the College Shop, where, under the general supervision of the teacher of the Elements of Commerce, they serve in turn at the counter and learn to handle real accounts.

The University Courses. These are intended for students who wish to prepare for any of the following external examinations of the University of London: Intermediate Arts, or Science, or Agriculture; the first examination for medical degrees; and the Intermediate and Final B.Sc. degree examinations in Engineering. Before he can be admitted to any of these courses a student must have passed or obtained exemption from the London Matriculation Examination. Students who wish to enter the Engineering course are required as a condition of acceptance to spend a preliminary period of six weeks in engineering works and are not accepted unless they are favourably reported on by the Works Manager.

Of the 33 students in the University Classes, 8 were previously educated at Achimota, while the rest came from other schools in the Gold Coast and in Nigeria. In the years 1932 to 1937,32 students passed out of the University classes. From such information as is available in regard to the subsequent careers of these students it would appear that I I have entered the teaching profession, 2 are in the Government Printing Press, and 2 others in the Civil Service. Two Engineering Students have entered the service of the Government Railways Departments, and 3, who did not complete the Engineering course, were being trained as assistant mill shift bosses in Konongo Gold Mines Ltd. Eight students proceeded to Great Britain for further studies, 5 among them being medical students.

\title{
The Practice of 'Uvaisi' among the Ovimbundu.
}

[Translator's note. The account of marriage customs among the Ovimbundu would not be complete without mention of the licit sexual telation known as waisi. Uvaisi is a sort of trial martiage having a certain counterpart in the New England colonial custom known as 'bundling'. It does not differ essentially from some forms of modern excitement known in recent American as ' petting'. Apparently the word waisi is related to the word for marriage, uwala. The ending isi indicates the causative stem; in this case it would mean that-which-causes-marriage. It is a common thing for the $l$ to be elided in Umbundu, thus walisi is waisi. It is very common to say zwaisi waño; waño means common, ordinary, inferior. I have asked, 'Why is it waño?' No one knows. The early missionaries in seeking for a word to indicate illicit sexual relations and sexual misbehaviour hit on this word and

$$
\mathrm{k} \mathrm{k}
$$


used it for adultery, fornication and other such. As wwaisi was a permitted and definitely regulated custom, not morally offensive, it is probable that some of the Christian teaching on sexual relations missed the mark. The following account is concise and accurate. Considering the stigma attached to the loss of virginity it must be assumed that there was no actual connexion.]

Here is a statement of the old-time Umbundu custom of wvaisi. The young men and girls who lived together in one village or in a group of villages were those who were more given to this custom. A young man who was in love with a girl would say to some of the others of his own age, 'I say, that girl Ngandi (what's-her-name), I am in love with her. If she will agree she will be my steady (ombaisi).' 'The others say, 'Right, if you have spoken to our elder Ngandi (so-and-so), we shall go in the evening.' 'Then in the afternoon the young man who is in love with the girl will go to his elder and say, ' $O$ elder brother, I am in love with Ngandi's daughter, will you go and accompany me this evening to see if she will be my steady?' The elder says, 'Now this, is this leading to marriage, or is it just ordinary petting?' The youth says, 'Just ordinary petting is what I want.'

Then when it is evening the youth and his friends and the older person they have asked all go to the kitchen of the girls. First, after they have made glad over them, they ask them to sit down. If there is an older one among the girls she will speak, saying, "How is it now, do we die to-day or do we escape?' Then the youths will say, 'You escape.' Then the elder of the youths will speak and say, "We have come about this child here, Ngandi, for this youth here, Ngandi, is in love with her, he wishes to know if she agrees that they pet each other.' 'The girl in question, if she is in love with the youth, will hang her head and not say anything. If there is some one of the girls who acts as elder she will whisper to the girl and say, 'Now this, did you hear it? How shall we reply?' Then the girl will reply and say, 'I, I do not know, only my parents or an elder.'

And then on another day the youths will go to the parents. The elder will speak to the parents and say, "We have come for nothing except for the word of your daughter, Ngandi. Since she is mutually in love with this youth, Ngandi, does not the word rest with you?' They, the parents, reply and say, 'Now then, is this just ordinary petting?' The youth will reply and say, 'Just ordinary petting, not marriage.' Then the parents will reply and say, 'All right, we, if the girl agrees, we agree also.'

After the youths are gone, if the girl has paternal aunts, they call her and say to her, "As to the petting which you and Ngandi wish, we do not wish any shame-making-happenings. 'A person,', they do not do each other

I An elliptical statement of a sort common to Umbundu speech. It indicates that the girl is a respectable person, belonging to a respectable family, entering into a respectable relationship with another of the same category, and therefore they are expected to act the part. 
scandalous things. If you perceive that this man is smitten with you and he takes hold of the cloth which you wear, insult him and say, "You are a dog, you are an animal", then straight off in the middle of the night get out of there.'

Then on that evening, on the day the word is finished, the youth sends his messenger to the girls' kitchen to fetch the girl, and so they do right on every evening. Then when a month has gone by the youth will make payment. They call this payment the-offering-to-the-parents-in-law. Some girls, if they have an inkling of some of the traits of the youth and they do not like them, when he makes the parents-in-law gift they will not consent to go again. They say, 'In that youth's bed it has begun to bite.' Then the people say, 'Ngandi and Ngandi have broken off, but the separation is peaceful.' If it should happen that the youth began to be funny with the girl she will come out of the house and shout insults at the youth so that all the village will hear that that youth is not what he should be.

If the youth is a person indeed he does not wish to do himself despite, and if the girl is of the same mind they may keep up the relationship for a long time. Sometimes it may happen that that which was just ordinary petting may lead them to take the word back to the parents and then it becomes an engagement for marriage, but in that case they may not send for each other any more. If the youth loves some one else and they are mutually agreeable it is permissible that they marry, and so it is with the girl. In many cases they separate and the girl marries some other youth and the youth marries some other girl, and everything is all right, nothing has happened. (Communicated by the Rev. MerLIN W. EnNis who translated the original text of PAULINo GONGA LIAHUKa.)

\section{Inter-Territorial Language Committee (for Swahili).}

THrs Committee, which is doing useful work in standardizing Swahili and in promoting vernacular literature, has added to its strength by co-opting non-European members representing their respective territories, Kenya, Tanganyika, Uganda, and Zanzibar.

At its last meeting, which was held in January of this year, the Committee suggested the advisability of a wider policy of language and literacy and asked the Directors of Education to consider means for the provision of literature for adult readers and in that connexion to approach their respective Governments with a view to the production of literature in the major vernaculars of the territory concerned.

The annual Swahili essay competition, inaugurated by the Committee in 1935, is maintained with increasing popularity. The degree of interest in this competition is revealed by the fact that over 500 essays have been submitted.

The number of books and pamphlets submitted to the Committee for 